REVISTA de

PEDAGOGIE

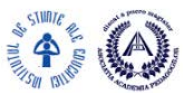

JOURNAL of

PEDAGOGY

http://revped.ise.ro

Print ISSN 0034-8678; Online ISSN: 2559 - 639X

\title{
THE USE OF TECHNOLOGY IN STEM EDUCATION. AN EMPIRICAL RESEARCH
}

UTILIZAREA TEHNOLOGIEI ÎN PREDAREA DISCIPLINELOR STEM. O CERCETARE EMPIRICĂ

\section{Olimpius ISTRATE, Cosmina MIRONOV, Anca POPOVICI}

\author{
Journal of Pedagogy, 2019 (1), 73 - 91 \\ https://doi.org/10.26755/RevPed/2019.1/73
}

The online version of this article can be found at: http://revped.ise.ro/category/2019-en/

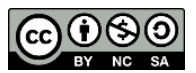

This work is licensed under the Creative Commons Attribution-NonCommercial-ShareAlike 4.0 International License.

To view a copy of this license, visit http://creativecommons.org/licenses/by-nc-sa/4.0/ or send a letter to Creative Commons, PO Box 1866, Mountain View, CA 94042, USA.

Published by:

\section{INSTITUTUL DE ȘTIINȚE ALE EDUCAȚIEI}

http://www.ise.ro/

Further information about Revista de Pedagogie - Journal of Pedagogy can be found at:

Editorial Policy: http://revped.ise.ro/editorial-policy/

Author Guidelines: http://revped.ise.ro/the-writer-guide-2/ 


\title{
THE USE OF TECHNOLOGY IN STEM EDUCATION. AN EMPIRICAL RESEARCH
}

\author{
Olimpius Istrate, Cosmina Mironov, Anca Popovici* \\ University of Bucharest, Faculty of Psychology and Educational Sciences \\ Bucharest, Romania \\ olimpius.istrate@unibuc.ro, cosmina.mironov@fpse.unibuc.ro, \\ anca.popovici@fpse.unibuc.ro
}

\begin{abstract}
In Romania, the latest results in PISA as well as national exams show a decrease in the interest of students in studying sciences, whilst the results are much below the OECD average. The present study has been carried out at national level by a research team from the University of Bucharest within the framework of the international Horizon 2020 project Scientix, coordinated by European SchoolNet. The study addresses the beliefs and attitudes of STEM teachers in the pre-university education on current practices, evolution and trends in the science-related skills of students. Two investigative techniques have been used: document analysis and an online standardized questionnaire-based survey. The questionnaire was developed by Friday Institute for Educational Innovation, NC State University. So far, the quantitative data was collected from 259 STEM teachers.

The survey invited teachers to express their opinions related to their attitudes, values and beliefs on their teaching efficacy, development of the $21^{\text {st }}$ Century skills, educational leadership, as well as some other themes such as the extent to which teaching and teachers affect student learning, the amount and quality of use of ICT for learning in STEM classes, the frequency of using certain STEM instructional practices, awareness of STEM careers.

This article's focus is on one out of the seven constructs - the use of technology in STEM classes. The construct is operationalised in eight sub-items. The discussion on the each of the constructs as well as on the relations between them is quite relevant in the light of the relationship between beliefs and practices, while the results are quite striking, with impact on tailored professional development approached.
\end{abstract}

* Associate Professors, PhD., University of Bucharest, Faculty of Psychology and Educational Sciences, Bucharest, Romania. 
Keywords: computer-assisted instruction, ICT tools in education, teachers, STEM education.

\section{Rezumat}

In Romania, rezultatele ultimei evaluări PISA, precum şi rezultatele examenelor na ionale arată o scădere a interesului elevilor în studiul ştiin elor, iar rezultatele sunt cu mult sub media OCDE. Studiul de fa ă a fost implementat la nivel na ional de către o echipă de cercetare de la Universitatea din Bucureşti, în cadrul proiectului Scientix, coordonat de European SchoolNet. Cercetarea vizează credin ele şi atitudinile cadrelor didactice care predau discipline STEM la nivel preuniversitar privind practicile curente, evolu iile şi tendin ele în educa ia pentru ştiin e. Au fost utilizate două tehnici investigative: analiza de documente şi ancheta pe bază de chestionar online standardizat. Chestionarul a fost dezvoltat de Friday Institute for Educational Innovation, NC State University. Până în acest moment, au fost colectate date de la 259 de cadre didactice care predau STEM.

Ancheta a invitat profesorii să îşi exprime opinii pentru a surprinde atitudinile, valorile şi credin ele pe teme precum eficacitatea demersurilor de predare, dezvoltarea competen elor pentru secolul XXI, leadership educa ional, măsura în care predarea şi cadrele didactice influen ează performan a şcolară la disciplinele STEM, măsura utilizării TIC, frecven a anumitor strategii didactice la lec ii de STEM, constientizarea carierelor profesionale in domeniile STEM.

Articolul abordează prioritar un construct important (dintre cele şapte vizate de investiga ie) - utilizarea tehnologiilor informa iei şi comunicării în activită ile de învă are la disciplinele STEM. Constructul este opera ionalizat în opt elemente. Cadrul mai larg al dinamicii dintre constructe este relevant pentru a în elege atât rela iile dintre credin e şi practica educa ională, cât şi modul în care rezultatele cercetării pot fi utilizate pentru a proiecta parcursuri de dezvoltare profesională continuă pentru cadrele didactice care predau discipline STEM.

Cuvinte cheie: cadre didactice, instruire asistată de calculator, resurse şi instrumente educa ionale digitale, STEM, educa ie pentru ştiin e.

\section{STEM Education - European Context and National Approach}

Providing an overview of competitiveness in 140 countries, the World Competitiveness Report 2015-2016 (Schwab, 2015) reveals that education reforms must be a key focus of the governments' agenda to increase the competitiveness of the economy today, an economy based on innovation, technology and entrepreneurship. The importance of science and technology 
for economic prosperity, social welfare and sustainable development is widely recognized. In this respect, science education has been a major priority to ensure that a sufficient number of students will continue their studies for a career in science, technology and engineering (European Commission, 2015).

\subsection{Training for a Changing Labour Market}

STEM is a collection of scientific fields with the fastest growing impact on the corresponding school disciplines. Generally speaking, there should be more interaction between science, labour market and research education to give the pupil a goal, a real commitment to science, and those skills that will really serve his later career path.

A study on the challenges of science education, developed by the European SchoolNet, points to the fact that in Asia, the interest in developing competences in science is high for about $20 \%$ of students, while in Europe it is only $2 \%$. The first three factors that should be addressed in the near future are (1) negative perceptions and stereotypes about STEM and its role in society, (2) the lack of policy connections: the disjunction between government policies and industry practice, evident primarily by the discrepancy between declared priorities and poor support (through adequate investment in education), (3) the lack of inspirational models, low involvement and motivation for career in science, largely caused by negative experience in within the school disciplines in the STEM area.

Analysis of connections between disciplines and professions shows that interest in discipline can increase interest in different professions. Also, interest in a particular profession can strengthen the understanding of a discipline. It is possible that the same profession is associated with several disciplines. This means that when choosing a career or shaping a life plan, students have multiple options, each of which can be embodied in various professions. Students should be helped to understand, from an early age, what job is close to their skills, inclinations and interests, and also to be informed about the links between disciplines and one or more professions. In order to ensure the attractiveness of studying the STEM disciplines, they need to be updated with new themes, corresponding to the dynamics of the 
sciences and the needs of the labour market. Exact sciences and technologies have revolutionized the past ten years - nanotechnology, computerization, innovation in engineering. In contrast, the contents of the STEM disciplines are preserved and reorganized rather than up-to-date, and the number of hours in the curriculum is progressively reduced.

Teachers teaching subjects in the STEM area need support and professional development in the effective implementation of teaching strategies and in updating the understanding of learning outcomes (key competencies, including the " $21^{\text {st }}$ Century skills") in the context of contemporary education.

Professions unknown so far have arisen due to advances in science and technology. There is a great demand for a new type of human resources in almost all professional fields linked to STEM competencies.

The education system is neither flexible, nor adaptable enough to incorporate rapid change - in these conditions, it can hardly be proactive in the professions that do not yet exist. However, skills for new jobs can be, to a large extent, anticipated: there is a direct link between new jobs and the development of science.

Still, despite all efforts to popularize science over the past decades, learning systems fail to attract enough students. Traditionally, many formal and informal science initiatives have been based on the belief that if sciences can be made more interesting than careers in related fields would become more attractive (Archer, DeWitt \& Wong, 2014). Recent significant studies (ASPIRES - Archer \& all, 2013) show that the problem is not just a lack of interest. Moreover, the negative view on sciences and scientists is not the problem. Students have a good idea about scientists, and their parents think it is important for them to study science. Despite these positive views of the majority, few of the 10-14-year-olds aspire to a career in science. These studies have identified the factors that explain why 10 to 14-year-olds want or do not want a scientific career. Factors consist in what students believe, what they know, what they do and who they know - together, being called the "capital of science". Low-science students are those who have little knowledge of science and low confidence in their own skills and abilities, 
poor participation in science outside school, and not much talking about home-based science and whose families or social groups are not interested in science and tend not to include people with science trades. The authors of the study found that these factors have a strong prediction potential for guiding students to careers in science. From the "capital of science" perspective, studies reveal aspects of the current situation that indicate why the study of science is not attractive to students. Particularly, students often do not see the relevance of science, which seems abstract and distant; most students do not see beyond the career of researcher when it comes to science occupations. They were not aware of their transferability in a wide range of careers; students with limited science capital rarely have contact with scientists, so it is not surprising that they know little about the variety of scientific careers and what they are supposed to do. Most significantly, one cannot imagine having a job in a scientific field.

The model of intentional learning (Boyatzis \& Akrivou, 2006) is based on the idea that people are motivated to develop certain competencies only to the extent that they perceive the beneficial and meaningful change for them. As a result, in order to be sustainable, any change must start from what is important in the context of everyone's life and community and society to which he or she belongs. The challenge is therefore to reveal what is important to the context of today's and future life, to raise awareness of the relevance of science, to highlight their transferability in a wide range of careers, to ensure access to and constant interaction with science professionals, and to activate family members in the STEM area, for example, through "citizen science" projects.

\subsection{Curriculum Reform in Romania: STEM disciplines}

Romania prioritises the education in STEM domains through the National Strategy for Education 2020. The curriculum reform is implemented following the studies carried out on education in Romania, the numerous pilot programs funded by the European Social Fund, as well as the results obtained by the students in the sciences in the PISA and TIMSS tests. The most prominent aspects of this curricular reform, as they were included in the methodological suggestions in the national school curriculum for STEM 
disciplines, are: promoting inquiry-based learning; promoting context-based teaching with approaches centred on socio-economic aspects of science (aspects of everyday life and current issues); promoting small-group discussions during science classes. In addition, these teaching-learning strategies are also assessed in the current evaluations of schools and teachers (e.g., during the process of professional development: "definitive" teacher, teaching degrees, performance, etc.).

The curriculum reform started in 2013 stipulates, for the first three classes in primary education, that mathematics is studied integrated with science within a new discipline called Mathematics and Environment Exploration. Due to the fact that the development of new technologies is one of the goals of the sustainable development of the economy, education in STEM disciplines has high chances to remain a priority in the near future.

Romania has benefited from several projects funded by the European Social Fund (ESF), which have been directly targeted on the continuous professional development of teachers. These projects, involving various partners at national level, have produced a wide range of mixed courses for teachers on different education themes. Moreover, the Ministry of National Education has endorsed several optional courses resulting from these ESFfunded projects, which are now taught in primary, secondary and high schools.

Teacher training activities are also carried out on e-learning platforms (e.g., iTeach - suntprofesor.ro - a CPD platform with courses and activities for teachers, then the project platform "MaST Network - Quality in the development of key competences for Mathematics, Sciences and Technology" and the project platform "Continuous training of Mathematics and Science teachers in the knowledge society").

To integrate the effective use of new technologies in STEM education, the most significant project, implemented by the National Evaluation and Examination Centre, is "Key ICT Competences in School Curriculum". Through this project, teachers who teach STEM disciplines have developed ICT skills, and digital resources specific to each discipline have been proposed. Besides the mentioned project, the Ministry of Education has implemented various other projects: "eSchool", "Digital Mathematics. 
Optional curriculum and educational resources for the 3rd Grade".

Several new strategic programs have been developed at national level to develop relevant ICT tools and educational resources, and to connect schools to the Internet: "CRED - relevant curriculum and open educational resources", "Internet in your school", "Wireless Campus - national integrated platform".

\section{STEM Education: Empirical Research Framework and Methodology}

An investigative approach was carried out within the framework of the Scientix international project, coordinated at European level by European SchoolNet. It continues the research initiated during the previous cycle of Scientix (Kearney, 2015) by complementing with specific data the current European approaches initiated within this project cycle (Nistor, 2018). The research conducted in 2015 had been seeking to obtain relevant data on national initiatives with an impact on increasing student motivation towards STEM education and choosing a professional career in this field. The 2018 research brings insights into the STEM disciplines and practices of teaching and learning.

The project team from the University of Bucharest (the National Contact Point for Scientix, since 2015) elaborated an evaluation research methodology, identifying the necessary tools and means to apply them. The present article is revealing a part of research findings, focusing on the use of technologies in STEM education practices.

The conceptual framework of the research is based on data and information on STEM training and - evaluation reports and recommendations developed in recent years in Europe and at national level. Relatively recent studies indicate the main landmarks of science education, providing useful information to circumscribe further local or focused researches: Recommendations for Educational Policies, material developed in November 2017 within the European TTTNet project (Teamwork, Training and Technology Network); Science, Technology, Engineering and 
Mathematics Education: A Survey of Challenges in Europe, a booklet published by European SchoolNet in 2011, a starting point for the European Scientix program (2011); ASPIRES - Young people's science and career aspirations, age 10-14, study conducted in the UK in December 2013 (2013). Accordingly, several contextual and local features justify our investigative approach:

- the need for qualified specialists in STEM-related fields to properly support the development of a dynamic and innovative knowledge-based society and economy;

- existing initiatives to integrate formal education with institutions, initiatives and resources supporting science education through non-formal approaches; developing and expanding non-formal education programs for STEM;

- support networks comprised by scientists, researchers and practitioners, through punctual support, directly or indirectly, through citizen science projects, etc.

- recent documents on European education recommendations and policies, as well as the increasing allocation of financial sources of funding from the EU for projects to promote, train, increase the attractiveness of science and science education;

- repeated reports in the Romanian public space on the programs and projects carried out or in progress, the focus on the transfer of the results of the scientific research projects and their extension within the educational system;

- the existence in Romania of extensive networks and among the most active at European level of teachers attached to different initiatives and projects (e.g., Scientix, ESERO, ROEDUSEIS, eTwinning, etc.) emphasizing the need to connect and participate in organizing and developing the system.

The research questions revolve around the following topics: which are the beliefs and attitudes of teachers related to their self-efficacy, classroom practices, use of technology, learning results and STEM related careers? Do these attitudes and beliefs explain in any way the actual results of students?

The aim of the investigation is to highlight the extent to which current 
STEM training practices in pre-university education contribute to the development of students' STEM competencies.

The investigative strategy is related to the priorities and trends identified in the area of science education, the characteristics of the investigated population and the effective investigation possibilities of the project team. Two investigative techniques were used: document analysis and standardized questionnaire survey to reveal views, underlying values, attitudes and trends in teaching practice, training content, available or needed resources, and the opportunity and the value of STEM education.

The questionnaire survey was chosen as main research tool in order to reach a significant number of teachers, being applied online. The grids composing it are standardized tools developed by the Friday Institute for Educational Innovation (2012), NC State University (Innovation, 2012). The table below presents the STEM survey summary as the authors proposed it and the details on each of the constructs included.

Table no. 1. [T-STEM Survey Summary]

\begin{tabular}{|l|l|}
\hline \multicolumn{1}{|c|}{ Construct } & \multicolumn{1}{c|}{ Measurement Application } \\
\hline $\begin{array}{l}\text { Personal Teaching Efficacy and } \\
\text { Beliefs }\end{array}$ & $\begin{array}{l}\text { self-efficacy and confidence related to teaching the specific } \\
\text { STEM subject }\end{array}$ \\
\hline $\begin{array}{l}\text { Teaching Outcome Expectancy } \\
\text { Beliefs }\end{array}$ & $\begin{array}{l}\text { degree to which the respondent believes, in general, student- } \\
\text { learning in the specific STEM subject can be impacted by } \\
\text { actions of teachers }\end{array}$ \\
\hline Student Technology Use & how often students use technology in the respondent's classes \\
\hline STEM Instruction & $\begin{array}{l}\text { how often the respondent uses certain STEM instructional } \\
\text { practices }\end{array}$ \\
\hline 21st Century Learning Attitudes & attitudes toward 21st century learning \\
\hline Teacher Leadership Attitudes & attitudes toward teacher leadership activities \\
\hline STEM Career Awareness & $\begin{array}{l}\text { awareness of STEM careers and where to find resources for } \\
\text { further information }\end{array}$ \\
\hline
\end{tabular}


The Personal Teaching Efficacy and Beliefs (PTEB) and the Teaching Outcome Expectancy Beliefs (TOEB) constructs were derived from a well-known survey of science teachers, the Science Teaching Efficacy Belief Instrument, or the STEBI (Riggs \& Enochs, 1990). The Student Technology Use construct was developed from the Student Technology Needs Assessment, or STNA (SERVE Center, 2005). The STEM Instruction construct was based on items that were developed by The Friday Institute and used in a state-wide evaluation of the professional development activities of North Carolina's Race to the Top grant (Corn, et al., 2013). The 21st century learning attitudes construct was adapted from the Friday Institute's Student Learning Conditions Survey (2011). Finally, each item in the Teacher Leadership Attitudes construct was taken from the North Carolina Department of Public Instruction's professional standards for educators (2012). The versions of the T-STEM Survey vary in the specific subject area referenced in the survey items. For example, one item is written in the Science T-STEM, "I am continuously improving my science teaching practice," and in the Math T-STEM the same item is written, "I am continuously improving my math teaching practice." The Elementary T-STEM includes both versions of the science-specific and math-specific items since most elementary teachers teach both. The $21^{\text {st }}$ Century Learning Attitudes, Teacher Leadership Attitudes and STEM Career Awareness sections, however, are identical across all five survey versions.

In this study, we did not intend to sample the target population, as by means of collecting the answers we get a sample of opportunity, made up of those people who have chosen to fill in the research tool we used. This method of investigation has some obvious advantages and disadvantages. As far as the benefits are concerned, it allows investigating as many people as possible in the target population. Of course, from a methodological perspective, the absence of a sampling rule may cause distortions due to exogenous factors of research, such as the quality of databases with contact data held by the investigative team, the availability of people to complete a research tool quite the level of individual interest in participating in such research, and others. We believe, however, that the influence of such factors is inherent in any social research approach, regardless of the sampling method. In addition, the use of an online research tool offers the opportunity to record a relatively large number of responses, higher than would be possible by 
applying face-to-face questionnaires.

A number of 259 Romanian teachers responded to the invitation to depict the current situation: the attitudes of the teachers in the pre-university education system towards the training activity, the results of the pupils' learning and their attitudes towards the use of technologies and current STEM education - physics, chemistry, biology, ICT, computer science, technology, engineering, mathematics.

Three quarters of the sample teachers are urban (76\%), and a quarter from rural areas (24\%), covering all counties in Romania, in different proportions. Primary education is represented by $22 \%$ of the sample of respondents, while secondary education comprises three quarters of the surveyed teachers.

Figure no. 1. Distribution of teachers sample by education levels

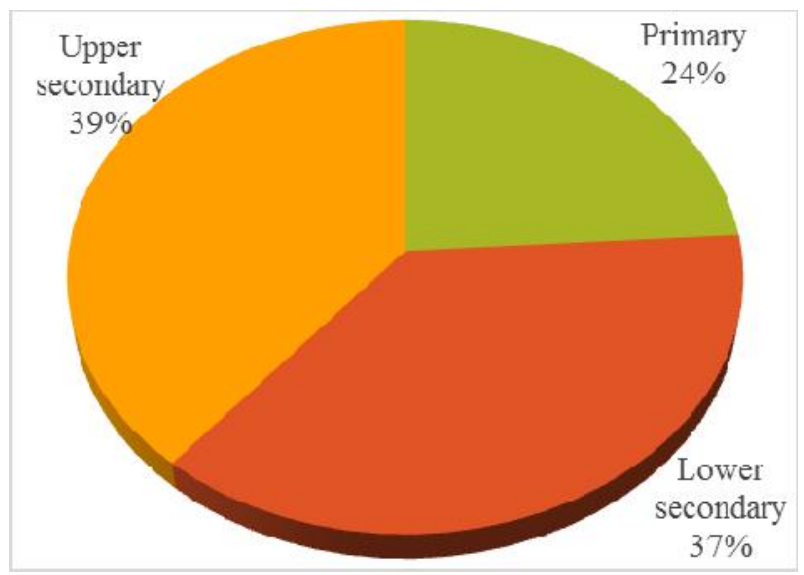

The disciplines taught by the respondent teachers are predominantly mathematics $(74 \%)$, chemistry $(52 \%)$, physics $(52 \%)$, computer science $(43 \%)$ and technologies $(43 \%)$. The disproportion of the number of teachers teaching mathematics in relation to the other categories can be explained by the higher number of teachers of this discipline within the education system, due to the high number of hours allocated to mathematics in the curriculum. 
As in most European countries, mathematics in Romania is taught as a compulsory discipline in both primary and lower secondary education, representing the main subject of the STEM category. At upper secondary level, the distribution tends to be diversified, according to the profile and specialization of the study paths.

In primary education, mathematics is taught interdisciplinary in the first two grades, alongside the other STEM disciplines, and has a monodisciplinary approach in the last three classes of this cycle. In lower-secondary education, pupils begin to be acquainted with other STEM disciplines: Biology $-5^{\text {th }}$ to $8^{\text {th }}$ grade, Physics $-6^{\text {th }}$ to $8^{\text {th }}$ grade, Chemistry $-7^{\text {th }}$ to $8^{\text {th }}$ grade, Informatics and ICT $-5^{\text {th }}$ to $8^{\text {th }}$ grade, mathematics continuing to keep a constant number of 4 hours per week. Mathematics is a compulsory discipline for the graduation of the gymnasium cycle, which counts for the admission at high school and for certain profiles and specializations, a baccalaureate subjects whose grade counts for admission to university studies.

From the point of view of experience in teaching, the sample is predominantly distributed in the age category of 21-30 years (43\%) and over 30 years $(27 \%)$, while $8 \%$ have less than 10 years old experience.

Figure no. 2. Distribution of teachers sample by teaching experience

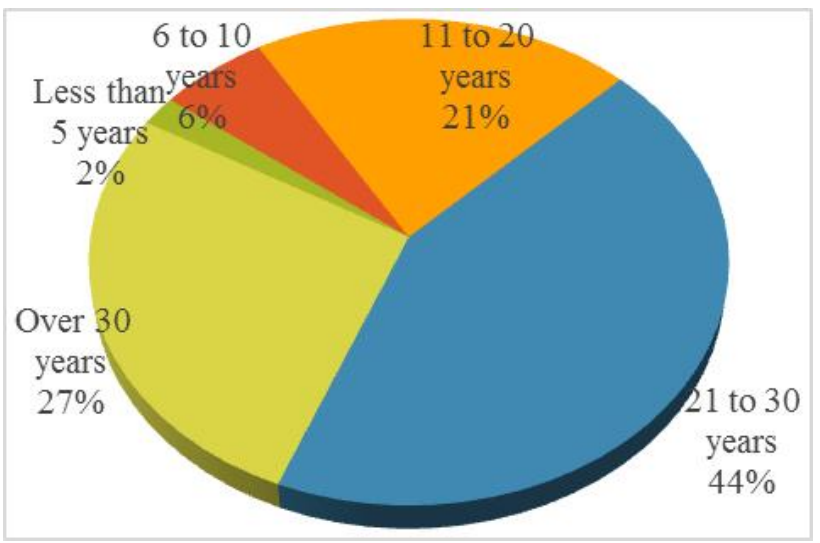


Most of the teachers participating in the research have the I-st didactic degree (84\%), a situation that reflects the distribution on the didactic degrees of the Romanian educational system.

$60 \%$ of teachers are connected to eTwinning professional networks and almost $35 \%$ are involved and are constantly pursuing Scientix activities. Only $16,21 \%$ of teachers admit they are not connected to a professional network. Other relevant professional networks gathering Romanian STEM teachers are the Romanian General Association of Teachers, the Romanian Mathematical Society, the Romanian Physical Society, the Romanian Chemistry Society or the European Resources Centre for Space Education - Romania (ESERO Romania).

\section{Use of Technology by Students - Data Analysis and Interpretation}

For essential reasons supporting an effective, applied, anchored and forward-looking education pathway, ICT tools are increasingly encountered in learning situations in Romanian education system. To them our investigation dedicates a series of questions, with the mention that in this context ICT is not an object (or content) of training, but a support that facilitates teaching, learning and assessment approaches to various disciplines (including Informatics or Technologies). The questions address the extent to which students use information and communication technologies during the teaching and learning activities proposed by teachers.

Urban ecosystems are privileged from this point of view, schools in cities being better equipped with computers and having better connectivity than rural schools. This enables students to use a variety of information and communication technologies in the education situations proposed by teachers in STEM disciplines: digital resources (online), tools to increase efficiency and productivity, tools that enable data visualisation, research tools and communication media. 
Figure no. 3. The extent to which students are using ICT in STEM classes. Rural-urban distribution

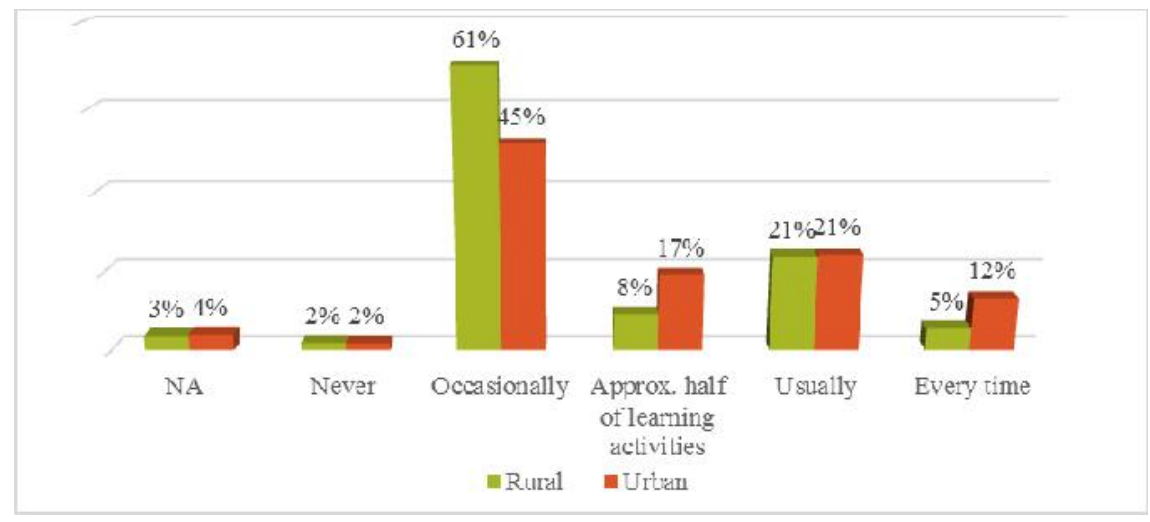

STEM education in primary "keeps up" with technological change, benefiting equally from the advantages of introducing new technologies compared to lower and upper secondary cycles.

Figure no. 4. The extent to which students are using ICT in STEM classes. Distribution by cycles

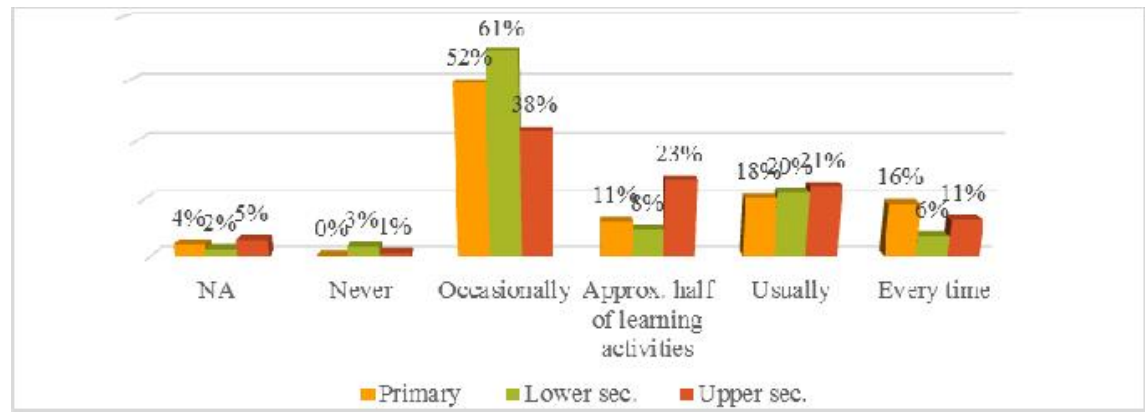

The reasons for which an education situation calls for new technologies can be very diverse, with the most prominent categories being (1) collaboration - the use of ICT to communicate and collaborate with other colleagues, possibly beyond the classroom, in homework or in eTwinning collaborative projects, as well as (2) documentation - use of technologies to access online resources and information as part of the educational activities 
carried out. Teachers of STEM subjects propose to students both uses, in a fairly comparable degree.

Figure no. 5. Scope of using ICT - communication and collaboration vs. access to resources

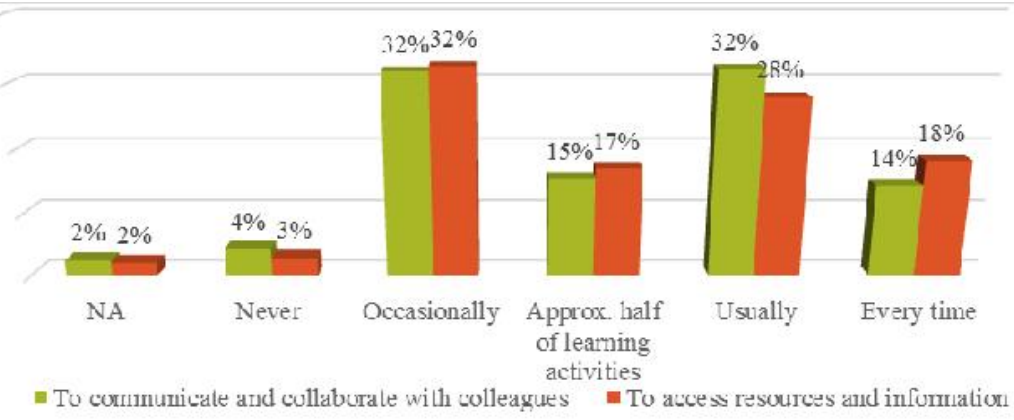

It also appears that the urban schools are more likely to offer students the opportunity to use the same types of tools that professional researchers use, such as simulations, databases, satellite images. Almost one in ten urban teachers proposes students with advanced tools every teaching hour of STEM disciplines.

Figure no. 6. Students are practicing with tools like those used by professional researches. Rural-urban distribution

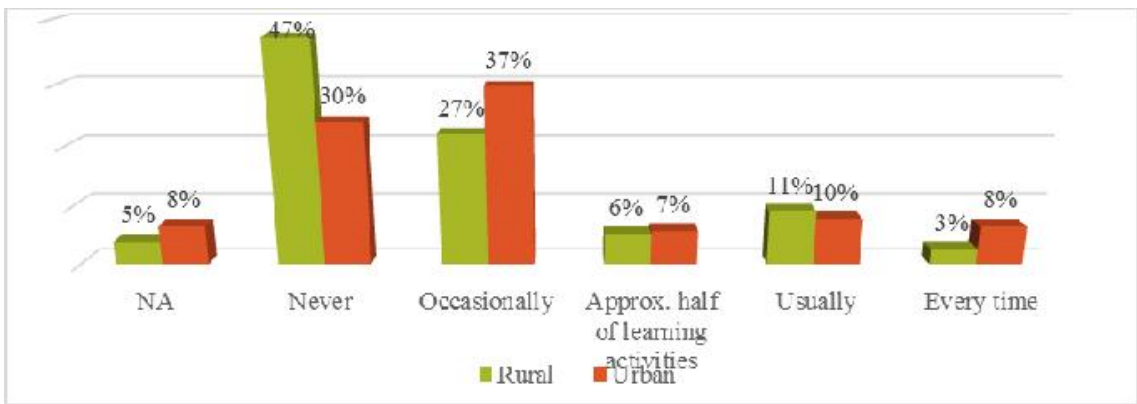

In high school education, these new resources and advanced tools are used to a greater extent than in lower secondary and primary education. In a 
percentage we consider very high, half of the gymnasium teachers declare that it is not the case $(4 \%)$ or never use $(45 \%)$ simulations, databases, satellite images, or similar tools in teaching and learning activities they carry out with students.

Figure no. 7. Students are practicing with tools like those used by professional researches. Distribution by cycles

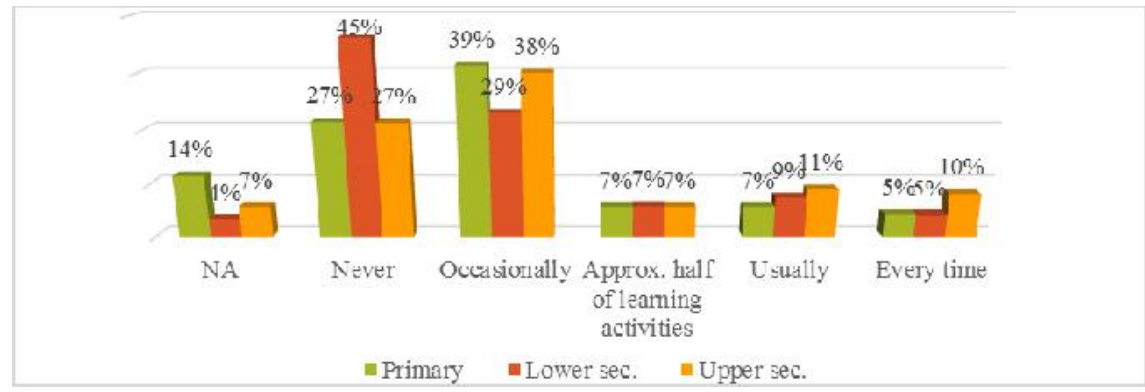

As far as training strategies are concerned, the project-based learning method seems to be sufficiently used, teachers saying they are inviting students to work on technology-assisted projects that focus on real-life applications in everyday life. Three quarters of students work on STEM projects, with ICT support, at least occasionally.

Figure no. 8. Working on applied projects, using ICT. Rural-urban distribution

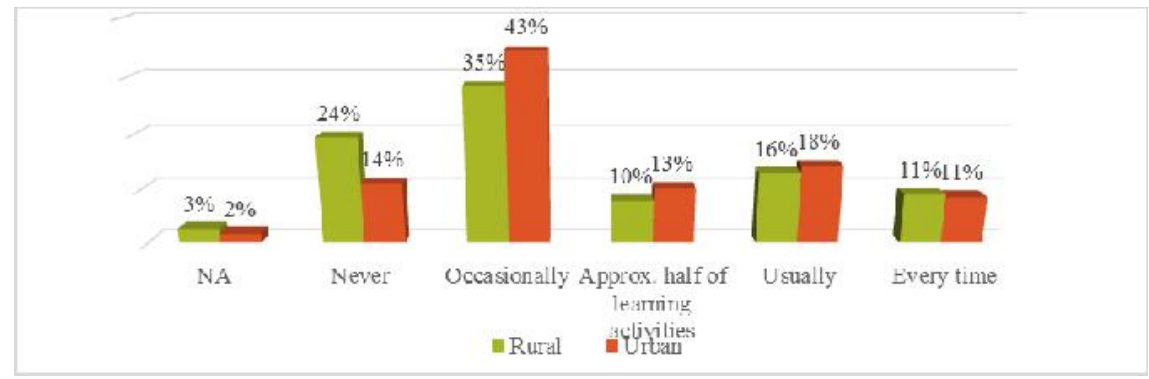


We would have expected the share of project-based learning activities to be lower in the primary cycle and to gradually increase towards high school, but teachers have relatively similar approaches in teaching science to smallage compared to secondary education.

Figure no. 9. Working on applied projects, using ICT. Distribution by cycles

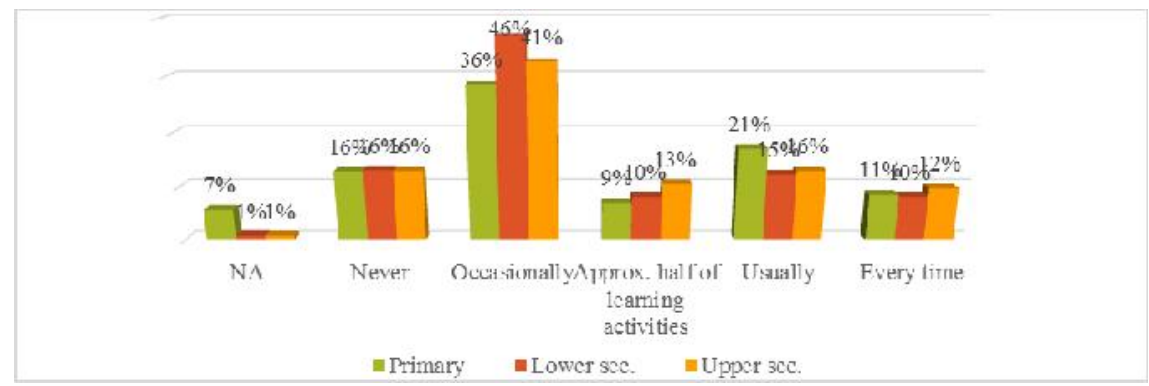

An equitable distribution is also to be met regarding the purposes for which digital resources and tools are integrated into STEM disciplines' learning activities. Students are equally taught, at least occasionally:

- to use technology to help solve problems,

- to use technologies to develop complex cognitive skills, such as analysis, synthesis and evaluation of ideas and information,

- to use technology to create or develop new ideas and new ways of representing information.

Figure no. 10. The extent to which students are taught to use digital tools, for different purposes

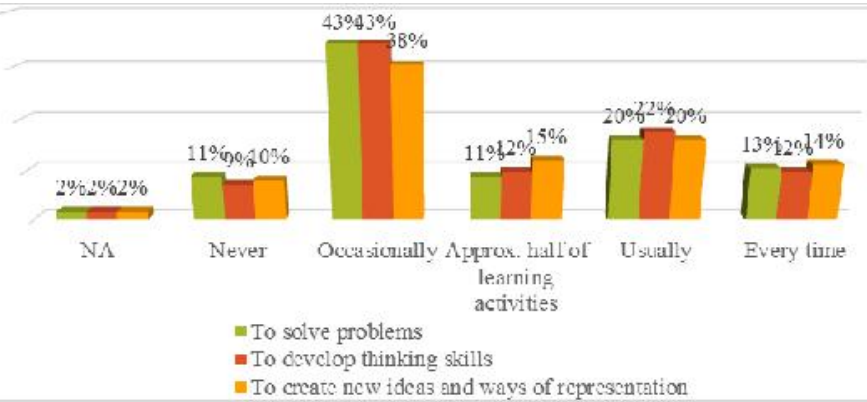




\section{Conclusions}

There are many ongoing efforts to document the importance or opportunity and value of STEM education as well as the use of technology in education, but few are aimed at transforming STEM education involving the use of technology and, moreover, grounding transformation directions on the basis of prospective analyses of teachers' values, attitudes and beliefs underlying the teaching practice, content of the training, available or necessary resources.

Based on our study in Romanian education system, some recommendations and directions of action can be identified on the component of use of technologies by STEM teachers and their students.

Firstly, there is a need to increase the use of digital resources and tools in STEM education activities, as a way to stimulate in-depth learning and to acquire $21^{\text {st }}$ century skills such as problem-solving, analysis, evaluation and critical thinking, collaboration, creativity.

Secondly, we must increase access to and interaction with certain scientists (researchers, inventors, theoreticians) and to get acquainted with the tools they use. This can be direct, through visits to institutes and research centres of innovation-development, but also mediated by technologies videoconferences, webinars, feeding common databases with local information, etc.

Not least, we would emphasize the need for a systematic and well-organized approach to the empowerment of teachers in STEM education areas, integrating the use of technology, by confronting and anchoring teachers' attitudes and beliefs in the reality of pupils, schools and community. This could be transposed into a strategy for STEM teacher training and professional development, based on transformational learning, impacting on authentic learning and careers in the STEM area.

\section{Acknowledgements:}

The authors would like to thank to Scientix Ro NCP team, in particular to Dr. Bogdan Popovici (IFIN-HH), for creating the framework for the research, 
as well as to Scientix Ambassadors who helped in disseminating the call for completing the research tools.

\section{References}

- Archer Ker, L., DeWitt, J., Osborne, J. F., Dillon, J. S., Wong, B., \& Willis, B. (2013). ASPIRES Report: Young people's science and career aspirations, age $10-14$. London, UK: King's College London.

- Archer, L., DeWitt, J., \& Wong, B. (2014). Spheres of influence: What shapes young people's aspirations at age 12/13 and what are the implications for education policy? Journal of Education Policy, 29(1), 58-85. https://doi.org/10.1080/02680939.2013.790079.

- Boyatzis, R., \& Akrivou, K. (2006). The ideal self as the driver of intentional change. Journal of Management Development, 25(7), 624-642. https://doi.org/10.1108/02621710610678454.

- European Commission (2015). Science Education for Responsible Citizenship.

- Innovation, F. I. (2012). Teacher Efficacy and Attitudes Toward STEM SurveyScience Teachers. Raleigh: NC.

- Kearney, C. (2015). Efforts to increase students' interest in pursuing STEM studies and careers: National Measures taken by 30 Countries - 2015 Report. Retrieved from: https://www.dzs.cz/file/3669/kearney-2016-nationalmeasures30-countries-2015-report-28002-29-pdf/

- Nistor, A. G.-V. (2018). Science, Technology, Engineering and Mathematics Education Practices in Europe. Scientix Observatory report. Brussels: European Schoolnet.

- Schwab, K. (2015). The Global Competitiveness Report 2015-2016. Geneva: World Economic Forum.

The online version of this article can be found at: http://revped.ise.ro/category/2019-en/

\section{(cc) EY-NC-BA}

This work is licensed under the Creative Commons Attribution-NonCommercial-ShareAlike 4.0 International License.

To view a copy of this license, visit http://creativecommons.org/licenses/by-nc-sa/4.0/ or send a letter to Creative Commons, PO Box 1866, Mountain View, CA 94042, USA.
Versiunea online a acestui articol poate fi găsită la: http://revped.ise.ro/category/2019-ro/

\section{(CC) BY-NC-SA}

Această lucrare este licen iată sub Creative Commons Attribution-NonCommercial-ShareAlike 4.0 International License.

Pentru a vedea o copie a acestei licen e, vizita $i$ http://creativecommons.org/licenses/by-nc-sa/4.0/ sau trimite i o scrisoare către Creative Commons, PO Box 1866, Mountain View, CA 94042, SUA. 